\title{
The Execution of Wills in California
}

JUDGE of a probate court, occasionally inclined to witticism, in commenting upon the frequency of attacks upon documents offered for probate as last wills of decedents, recently suggested that the adage "where there's a will there's a way" should now be changed to "where there's a will, there's a contest."

The official reports of the appellate courts in the state of California do not, by far, reflect the number of will contests which are entered. Most of them never reach the higher courts. These contests are, of course, predicated upon all or some of the grounds of contest recognized in this state ${ }^{1}$ and include: (a) The competency of the decedent to make a last will and testament; (b) The freedom of the deceased at the time of the execution of the will from duress, menace, fraud or undue influence; (c) The due execution and attestation of the will by the decedent or subscribing witnesses; or (d) Any other question substantially affecting the validity of the will.

It will not be our purpose, at this time, to present anything beyond the law of the state of California (as nearly as it may be ascertained from the statutes and decisions of the courts) upon what may be regarded the "due execution and attestation of the will by the decedent or subscribing witnesses."

Invariably laymen and, very frequently, members of the bar overlook the principle, now well established, that the right to make a testamentary disposition of property is not an inherent right nor a right of citizenship. It is not a right granted by either the federal or state constitutions. It rests wholly upon the legislative will and is derived entirely from the statutes. In conferring that right, the legislature has seen fit to prescribe certain exactions and requirements, looking to the execution and authentication of the instrument, and a compliance with these requirements becomes necessary to its exercise. ${ }^{2}$

1 Cal. Code Civ. Proc., \& 1312.

2 Estate of Rand (1882), 61 Cal. 468; Estate of McCabe (1886), 68 Cal. 519, 9 Pac. 554; Estate of Comassi (1895), 107 Cal. 1, 40 Pac. 15; Estate of Walker (1895), 110 Cal. 387, 42 Pac. 815; Estate of Patterson (1909), 155 Cal. 626, p. 635, 102 Pac. 941 ; Estate of Price (1910), 14 Cal. App. 462, 112 Pac. 482; Estate of Carpenter (1916), 172 Cal. 268, 156 Pac. 464; Cal. Code Civ. Proc., \$ 1969; Cal. Civ. Code, \$ 1276. 
It was suggested in an earlier case ${ }^{3}$ that, while the legislature has power to prescribe the formalities to be observed in the execution of wills, by so doing, it does not interfere with the right "from whatever source it may come" of disposing of property by will. It merely regulates the right and conserves it by reasonable formality.

From the legal maxim that "ignorance of the law is no excuse," follows the legal fiction that "everybody is presumed to know the law." The familiarization of those who are called upon to draft, execute or attest wills either for themselves or for others, with the statutory requirements thereupon, will be a long step toward the avoidance of successful attacks against wills upon the ground of lack of due execution, attestation or subscription by witnesses.

\section{I.}

Every person of sound mind and over the age of eighteen years may dispose of his property by last will. ${ }^{4}$ Every estate and interest in real or personal property may be disposed of by will, ${ }^{5}$ with certain exceptions. Upon the death of the wife, the entire community property, without administration, belongs to the surviving husband, except such portion thereof as may have been set apart to her, by judicial decree, for her support and maintenance, which portion is subject to her testamentary disposition. ${ }^{6}$ Upon the death of the husband, one-half of the community property goes to the surviving wife and only the other half is subject to the testamentary disposition of the husband. ${ }^{\text {T }}$

A testamentary disposition may be made to any person capable by law of taking the property so disposed of, except that corporations formed for scientific, literary, or solely educational or hospital purposes, cannot take under a will unless expressly authorized by statute. ${ }^{8}$ There is a further limitation in this regard to the effect that no property may be the subject of testamentary disposition to a charitable or benevolent society, or corporation, or to any person or persons in trust for charitable uses, unless the will is executed at least thirty days before the decease of the testator and unless, further, such total disposition does not exceed one-third of the estate of the testator leaving legal heirs. ${ }^{9}$

\footnotetext{
3 Estate of McCabe, supra, n. 2.

4 Cal. Civ. Code, \& 1270 .

5 Id., \& 1274.

B Id., \& 1401 .

7 Id., \$ 1402 .

8 Id., § 1275 .

' Id., § 1313 .
} 
If, after having made a will, a testator marries and has issue of such marriage, born either in his lifetime or after his death and the wife or issue survives him, the will is revoked, unless provision has been made for the wife by marriage contract, and for the issue by some settlement, or unless the wife and issue are provided for in the will or in such way mentioned therein as to show an intention not to make such provision. ${ }^{10}$ The marriage of a woman, subsequent to the execution of a will by her, operates as an absolute revocation and the will is not revived by the death of her husband."x

It is well to bear in mind that, when any testator omits to provide in his will for any of his children or for the issue of any deceased child, unless it appears that such omission was intentional, such child or the issue of such child is entitled to the same share in the estate of the testator as if he had died intestate. ${ }^{12}$ The same rule applies with reference to a child born after the making of the will, either in the lifetime of the testator or after his death, who is unprovided for by any settlement and not mentioned in the will. ${ }^{13}$

Although it is somewhat out of order to dwell upon the revocation of wills before there is a discussion of the execution of wills, yet, since we have already commented upon certain events which may operate to revoke a will, in whole or in part, we feel that it is proper to dispose briefly of this subject, bearing in mind that the primary purpose of this article is to discuss the due execution and attestation of wills by decedents or subscribing witnesses.

The revocation or alteration of a written will may be accoinplished either (I) By a written will, or other writing of the testator, declaring such revocation or alteration and executed with the same formalities (hereafter to be described) with which a will should be executed by such testator; or (2) By being burnt, torn, cancelled, obliterated or destroyed with the intent and for the purpose of revoking the will by the testator himself, or by soine person in his presence and by his direction. ${ }^{\text {th }}$

It is well to bear in mind that, when a will is cancelled or destroyed by any person other than the testator, the direction of the

10 Id., $\$ \S 1298,1299$.

1x Id., \$1300.

12 Id., \$ 1307.

13 Id., \$ 1306 .

14 Id., $\$ 1292$. 
festator and the fact of such injury or destruction must be proved by two witnesses. ${ }^{15}$

A subsequent will does not revoke a prior will, unless the subsequent will contains an express revocation, or provisions wholly inconsistent with the terms of the prior will. ${ }^{16}$ If, after making a will, the testator duly makes and executes a second will, revoking the first will, the destruction, cancellation or revocation of such second will does not revive the first will, unless it appears by the terms of the revocation of the second will that it was the intention of the testator to revive and give effect to the first will, and unless after such destruction, cancellation or revocation the first will is duly republished. ${ }^{17}$

The three kinds of wills which may be made are: 1st, the nuncupative; 2nd, the olographic; and 3rd, the attested. The olographic and attested will must be in writing, executed with certain formalities. ${ }^{18}$ A nuncupative will need not be in writing nor is it necessary that it be declared or attested with any formalities. ${ }^{10}$

\section{II.}

The nuncupative will is very rare. There is in fact no record, in the official reports of this state, of a nuncupative will ever having been offered for probate. This infrequency, together with the fact that recently many of our citizens, members of the National Guard, have been engaged "in actual military service in the field," and together with the additional fact that the United States of America have been drawn into the military maelstrom and have become a party to the world conflict now raging, makes it advisable to bear in mind under what circumstances a nuncupative will is valid.

To make a nuncupative will valid and to entitle it to be admitted to probate, the following requisites must be observed: (I) The estate must not exceed in value the sum of \$rooo. (2) It must be proved by two witnesses who were present at the making thereof, one of whom was asked by the testator at the time to bear witness that such was his will or to that effect. (3) The decedent must, at the time, have been in actual military service, in the field, or doing duty on ship board at sea and, in either case,

15 Id., § 1293.

16 Id., \& 1296.

17 Id., \& 1297.

18 Cal. Code Civ., Proc., \$ 1969; Cal. Civ. Code, $\S 1276,1277$.

19 Cal. Civ. Code, $\S 1288$. 
in actual contemplation, fear or peril of death, or decedent must have been, at the time, in expectation of immediate death from an injury received the same day. ${ }^{20}$

In order to entitle a nuncupative will to be probated, the testamentary words or the substance thereof must be reduced to writing within thirty days after they are spoken and it must be offered for probate within six months after they are spoken. ${ }^{21}$

Although there are a large number of adjudicated cases with reference to nuncupative wills from other jurisdictions, ${ }^{22}$ we will not pause to comment upon them, passing, rather, to the more important discussion of the execution of olographic and attested wills.

\section{III.}

An olographic will is one that is entirely written, dated and signed by the hand of the testator himself. It is subject to no other form and may be made in or out of this state and need not be witnessed. ${ }^{23}$ A paper, to constitute an olographic will, must therefore be entirely written, entirely dated and entirely signed by the hand of the testator himself. If it be partly written by him, or partly written by another or printed, if it be partly dated or signed by him and partly by another, it is not a compliance with the statute. ${ }^{24}$. The legislature has seen fit to require three things to concur for the execution of an olographic will and the courts are not at liberty to hold that the legislature intended any one of these requirements to be of greater or less importance than the other. If one may be omitted, why not either of the other? ${ }^{25}$

An olographic will must be entirely written by the hand of the testator. It may be informally drawn. No particular words are necessary to show a testamentary intent. It must appear only that the maker thereof intended by it to dispose of property after his death. ${ }^{28}$

Proper punctuation, spelling and precise phraseology are not essential. Courts, in reading wills, always supply obviously

20 Id., § 1289.

21 Id., \& 1290.

22 (See Kerr's Cyc. Civil Code, § 1290.)

23 Cal. Civ. Code, 1277.

24 Estate of Billings (1884), 64 Cal. 427, 1 Pac. 701.

25 Estate of Martin (1881), 58 Cal. 530.

26 Mitchell v. Donohue (1893), 100 Cal. 202, 34 Pac. 614; Estate of Silva (1915), 169 Cal. 116, 145 Pac. 1015; Estate of Scott (1900), 128 Cal. 57, 60 Pac. 527; Cal. Civ. Code, § 1328. 
omitted words, wherever the word omitted is apparent and no other word will supply the defect. ${ }^{27}$

A deceased left the following document as his will :28

"Crolldepdro, february 3, I892.

this is to serify that ie levet to mey wife Real and persnal and she to dispose for them as she wis.

Patrick Donohue"

The court construed the document to read as follows:

"Corral de Piedra, February 3, I892. This is to certify that I leave to iny wife (my) real and personal (property) and she can dispose of them as she wishes.

Patrick Donohue."

As thus construed, the court held that a testamentary intent was shown and, having been wholly written, dated and signed by the hand of the testator, it was adinitted to probate.

An olographic will may be in the form of a letter or several letters or a series of letters. ${ }^{29}$

In the Estate of Cook, ${ }^{30}$ the deceased had suffered for about twenty years froin a malignant disease and had reached the condition of physical disability, where the only hope for relief held out to her was through an operation which she had consented to undergo. On the day prior to her departure for the hospital for that purpose, she wrote three letters, one to a brother, another to her sister and brother jointly, and a third to a friend who was her business agent. She stated in these letters her intention of going to the hospital and that, while everything might turn out in her favor, she nevertheless felt that her condition was more serious than the doctor thought and that she had reason to believe that she might not live through it. She then proceeded to make a declaration of what she wished done respecting her funeral. She specified the cemetery and the lot in which she wished to be buried, the kind of headstone she wanted, the inscription to be placed upon it, and the name of the minister she wished to perform her funeral service. She then proceeded

27 Estate of Wood (1868), 36 Cal. 75; Mitchell v. Donohue, supra, $\mathrm{n}$. 26; Estate of Stratton (1896), 112 Cal. 513, 44 Pac. 1028; Estate of Goetz (1910), 13 Cal. App. 292, 109 Pac. 492; Estate of Silva, supra, n. 26.

28 Mitchell v. Donohue, supra, n. 26.

29 Clark v. Ransom (1875), 50 Cal. 595, Estate of Richardson (1892), 94 Cal. 63, 29 Pac. 484; Estate of Murphy (1894), 104 Cal. 554, 38 Pac. 543; Estate of Meade (1897), 118 Cal. 428, 50 Pac. 541; Estate of Cook (1916), $173 \mathrm{Cal} .465,160 \mathrm{Pac}$. 553; Estate of Anthony (1913), $21 \mathrm{Cal}$. App. 157, 131 Pac. 96.

30 Supra, n. 29. 
to make a disposition of her property. It was held, from all the circumstances under which the deceased wrote these letters and the language used, that they were obviously written animo testandi and were entitled to probate as a last will.

A document in the form of a letter ${ }^{31}$ was addressed to an undertaker and was dated sixteen months prior to the death of the writer. The main object of the letter was to provide for the disposition of the body of the writer in case of death, and the letter concluded with a statement that the estate of the writer must pay all expenses and further directed that a brother take charge of the estate as the sole administrator without bonds. The court concluded that the instrument was not of a testamentary character because the intention of the deceased that the paper should stand for a last will and testament was not clearly apparent. The main question in the mind of the deceased was the disposition of her body, not of her estate, and she simply communicated with the undertaker upon this point. Such being the principal purpose of the writing, the court suggested that it should have been made plain by apt words that, incidentally, she also intended the instrument to be her will.

In another case, ${ }^{32}$ the deceased wrote a letter to his sister expressing a desire for full information about his mother and about his sister's children, stating that he was pecuniarily independent, that his health was probably ruined, that he wanted to anticipate possibilities and containing the following language:

"You and your children get everything; your boy I want given the best of educations."

Here again, the court held that there was nothing in the circumstances and surroundings of the writer which unmistakably evinced an intention that the letter operate as a testamentary disposition of his estate.

In Clarke v. Ransom ${ }^{33}$ there was offered for probate the following instrument:

"Mayfield Grange,

Tuesday, June 23, 1874 .

Dear Old Nance: I wish to give you my watch, two shawls, and also five thousand dollars.

Your old friend

E. A. Gordon."

31 Estate of Meade, supra, n. 29.

32 Estate of Richardson, supra, n. 29.

33 Supra, n. 29. 
It was wholly in the handwriting of the deceased and was executed under the following circumstances. It appeared that for several years, the deceased and a Miss Ransom had been on terms of intimacy; that Miss Ransom was the person designated as "Dear Old Nance"; that the deceased was a widow, with a large estate and without children living; that she had executed a will in due form by which she had devised to her brother the whole of the estate, with the exception of several specific legacies, one of which was to Miss Ransom for one thousand dollars. After the will had been duly made and executed, the deceased desired to make a further provision for Miss Ransom and for that purpose she drew up, wholly in her own handwriting, the paper propounded as a will, and delivered it to Miss Ransom. From all these circumstances, the court found that the deceased intended that the instrument in question should take effect after her death.

In an early case, ${ }^{34}$ a document wholly in the handwriting of the deceased and properly dated and signed was admitted to probate. Under the third clause of the will, a bequest was made to the executor of certain personal property, requesting him "to dispose of the same in the manner specified in my letter to him of this date." After the execution of this will, the deceased dictated a letter to her executor. The letter was in the handwriting of the executor but was signed by the testatrix. The will was admitted to probate as an olographic will, but the letter was properly excluded. The rule announced was that any testamentary paper may be referred to and made a part of a will, if the reference be certain, unambiguous and definite, and if the paper be in existence at the time of the execution of the will..5

A letter forming one of a series of about thirty, written from time to time to the brother of the writer, informing him of the purchase of certain properties and stating that, "Both propertys goes to you and Charlie if I should pass in before yous do", was held not to be testamentary in character, where the surrounding circumstances showed that the writer understood the nature and requirements of a will, but did not make it plainly apparent that this particular letter was intended by him to be his will. ${ }^{36}$

34 Estate of Shillaber (1887), 74 Cal. 144, 15 Pac. 453.

35 Estate of Soher (1889), 78 Cal. 477, 21 Pac. 8; Estate of Young (1899), $123 \mathrm{Cal}$. 337, 55 Pac. 1011; Estate of Plumel (1907), 151 Cal. 77, 90 Pac. 192.

${ }_{38}$ Estate of Branick (1916), 172 Cal. 482, 157 Pac. 238; see also Estate of Anderson (1916), $173 \mathrm{Cal}$. 235. 
A letter duly dated and in the handwriting of deceased, consisting of two pages addressed to the person named as executor in an olographic will, to which the letter was attached, was enclosed with the will in an envelope upon which was endorsed the name of the decedent in his own handwriting. The letter was not signed. The letter contained nothing of a testamentary character except the expression of the opinion of the deceased as to the amount which the executor should receive for his services. The letter declared that the writer had "made a will." The court held that the animus testandi was lacking and denied probate to the letter. ${ }^{37}$

In the Estate of Skerrett, ${ }^{38}$ there was offered for probate a letter signed by the deceased and addressed to his sister. Accompanying the letter was a copy of a deed of gift from the deceased to his sister, conveying certain real property. It appeared from the face of the letter that the property described in the deed was intended by the deceased as a provision for his sister after his death. The letter was not dated, while the copy of the deed was dated. The copy of the deed and the letter were entirely written by the hand of the deceased and signed by him. The letter contained the following langnage:

"We all know life is uncertain and we don't know the moment we may be called away .... I therefore want you to know you are provided for under any circumstances. . . . . $\mathrm{My}$ intention is to provide for you while I live, the same as I have always done, and hereafter, if it should please God to call me away, you will have your own property to depend on, sufficient to make you independent while you live."

The court found that the copy of the deed and the letter, as a whole, showed animus testandi and accordingly admitted them to probate. The court indicated that neither the copy of the deed nor the letter, by itself, constituted a will, for the one was not testamentary and the other had no date; but, taking them together as the deceased left them, one document was formed which should be regarded as a complete testamentary scheme taking effect only upon his death.

While a will (either olographic or attested) may be in the form of a deed, yet in order to entitle it to probate as a will, the instrument must not only contain words of testamentary character 
but must likewise satisfy the requirements of execution and must give every evidence of having been intended as a will. ${ }^{39}$

An instrument in the form of a deed granting and transferring, in praesenti, certain property to the grantee named therein but reserving its enjoyment until the death of the grantor was held to be no will. ${ }^{40}$

It has been said that the essential characteristic of an instrument testamentary in its nature is that it operates only upon and by reason of the death of the maker. $U_{p}$ to that time it is ambulatory. By its execution the maker parts with no rights and divests himself of no modicum of his estate. The death of the maker establishes, for the first time, the character of the instrument. It at once ceases to be ambulatory and acquires a fixed status and its admission to probate serves as a judicial declaration of that status. $^{41}$

In the Estate of Skerrett, ${ }^{42}$ the original deed of gift was offered for probate as a will. It was acknowledged as a deed but witnessed in the presence of two witnesses, who testified that the deceased had declared to them that the deed was his will and that they signed the deed in the presence of and at the request of the deceased. Containing no testamentary words and expressing no design other than a deed, the court held that it was not a will. It appeared in this case that the deed had never been delivered and, as the Supreme Court later expressed itself, ${ }^{43}$ if a deed prove to be inoperative, as such, that fact cannot turn a deed into a will.

An instrument entirely written, dated and signed by the hand of the deceased appeared to be more than an itemized list of the property belonging to the deceased, followed by these words:

"At my death all the above property and any other property that may be found to belong to me is to go to my wife and to her alone and I omit intentionally all other members of my family."

The court admitted this document as a will. ${ }^{44}$

An olographic will may be written upon more than one sheet

39 Adams v. Lansing (1861), $17 \mathrm{Cal}$. 629; Estate of Skerrett, supra, n. 38; Estate of Hall (1906), 149 Cal. 143, 84 Pac. 839 ; see also, Williams v. Kidd (1915), 170 Cal. 631, 637, 151 Pac. 1.

40 Estate of Hall, supra, n. 39.

41 Nichols v. Emery (1895), 109 Cal. 323, 41 Pac. 1089.

42 Supra, n. 38.

43 Estate of Hall, supra, n. 39.

44 Estate of Clisby (1904), 145 Cal. 407, 78 Pac. 964. 
of paper and these separate sheets of paper, (provided they satisfy the requirements of being entirely written, dated and signed by the hand of the testator) comprising one continuous instrument or a complete testamentary scheme, will be considered as a single document and be admitted to probate as a will.45 It is not necessary, when a will consists of several detached and separate sheets of paper, that the sheets be fastened together by mechanical or other device. ${ }^{46}$

The preceding decisions with reference to the form of an olographic will apply, in part, to attested wills; for, if an attested will satisfies the requirements of the ${ } \mathrm{w}^{47}$ as to execution, it is entitled to probate, no matter what its form, phraseology, spelling or punctuation may be, so long as an animus testandi is apparent.

IV.

The first prerequisite of an olographic will, testamentary language appearing as above noted, is that it be entirely written by the hand of the deceased.

In the Estate of Rand, ${ }^{48}$ the deceased purchased a stationer's blank and filled in certain blank spaces in his own handwriting. Other portions of the instrument were in print. The will was not attested, although the attestation clause was printed as a part of the instrument but left blank. The only theory, therefore, upon which the instrument could be regarded as the will of the deceased was that it was olographic. Since portions of the instrument were printed, it was not "entirely written" by the hand of the deceased and the statute had not been satisfied. It was urged upon the court that, as these portions of the instrument which were written by the deceased could, by themselves, constitute a will, the court should admit those portions to probate, omitting the printed portions of the instrument. The court declined to adopt this view. To have done so would have effected a change in the statute and made it read that such portions of an instrument as are in the handwriting of the deceased constitute an olographic will. The instrument must stand or fall as an entirety and unless it is entirely written by the hand of the deceased the statute is not satisfied.

45 Estate of Taylor (1899), 126 Cal. 97, 58 Pac. 454; Estate of Merryfield (1914), 167 Cal. 729, 141 Pac. 259; Estate of Keith, supra, n. 37.

46 Estate of Merryfield, supra, n. 45.

47 Cal. Civ. Code, \& 1276.

48 (1882), 61 Cal. 468. 
In the Estate of Dreyfus ${ }^{48 a}$ the decedent himself wrote a testamentary document on a typewriting machine. The document was wholly in typewriting, except the signature of the decedent thereto, which signature was written by the decendent with pen and ink. It was urged that the will was made wholly by the deceased, and since the deceased had himself manipulated the typewriting machine, it could be said that the document had been made "by the hand of the testator himself." The court held that:

"The language of sec. 1277, by the common usage of the language in 1872 , or even at the present time, would mean that the entire will must be in the "handwriting' of the testator. This would not include any sort of printing by the use of type, whether of a printing press or placed at the end of a rod manipulated by keys. . . . The process of making letters on paper with a typewriter is essentially a process of printing. The type, fixed on a bar, is stained with ink, and then pressed against the paper, leaving its imprint, precisely as in a printing press. The word 'written' as used in sec. 1277 , in the year 1872, had no such significance."

The court indicated that to extend the meaning of sec. 1277 of the Civil Code to include documents typewritten or printed by the hands of persons attempting to make testamentary documents "would greatly enlarge the opportunities for successful forgeries by taking away the means of detection which the legislature had in mind, and would defeat the purpose of the statute by destroying the safeguards which its requirements were designed to secure."

Before proceeding to the next prerequisite of olographic wills, it is perhaps advisable to dispose of one further matter with reference to testaments in general. Particular stress has been laid upon the necessity of an instrument offered as a will to show an animus testandi. This character in a document may be apparent even though no property is disposed of. The mere nomination of an executor, without making any disposition of one's estate or giving any other direction whatever, constitutes a will and renders it necessary that the instrument be established in the probate court. ${ }^{49}$ The fact that a testator nominates an executor but without giving a legacy or devising any part of his property makes it, nevertheless, a will. It may often occur that, subject to the payment of his just debts, a testator is quite willing that his property shall be succeeded to as provided by law, while the selec-

$48 a$ Estate of Dreyfus, Cal. Supreme Court, June 9, 1917.

49 Estate of Hickman (1894), 101 Cal. 609, 36 Pac. 118. 
tion of the person through whom the settlement is to be made and the distribution is to be had, is not only a matter of deep interest to him, but of vital interest to the estate. As the law accords to an individual the privilege of making his selection of an executor, the courts must uphold it when the selection is properly made.

\section{$\mathrm{V}$.}

An olographic will must be entirely dated by the hand of the testator. What is a date? In what does it consist? Must the date be correct? Must it be complete? May it be abbreviated? İs a date essential?

Where a paper which was presented for probate as a will was entirely written and signed by the hand of the deceased but bore no date and was not witnessed, it was held that the statute had not been complied with. ${ }^{50}$ It was urged that the dating of a will was a mere formal matter and not absolutely necessary; but the court held that three pre-requisites to the validity of olographic wills were imposed by the legislature, and that the courts were not at liberty to hold that the legislature intended any one of the three requirements to be of greater or less importance than the other. A recital appeared in the instrument to the effect that the deceased was of the age of sixty years; but the court held that this recital did not constitute a date, for it did not appear when he was of the age of sixty years, for he might have been at that age one day before his decease or ten years prior thereto.

In the later case, ${ }^{51}$ the instrument offered as the will of the deceased was olographic and bore a date written between the body of the will and signature in the following form: "Febr. I2, '98'. It was conceded that the body of the will and the signature were in the handwriting of the deceased. The court, however, denied probate upon the ground that the date was not im the handwriting of the deceased.

The term "date" has been held to mean "day, month and year" and the omission of any one of these will be regarded as fatal to an olographic will.52 While most of the standard dictionaries and many decisions from other jurisdictions define "date" as including "place" as well as day, month and year, it may be said to be firmly established in this state that "place" is not essential to a dating.

50 Estate of Martin (1881), 58 Cal. 530.

51 Estate of Behrens (1900), 130 Cal. 416, 62 Pac. 603.

52 Estate of Price (1910), 14 Cal. App. 462, 112 Pac. 482; Estate of Carpenter (1916), 172 Cal. 268, 156 Pac. 464. 
An olographic will may be made in or out of this state ${ }^{53}$ and the place of its execution is therefore of no moment. A letter dated "San Francisco 27, 191 I" was held invalid because of the omission of the month in the date. ${ }^{54}$ An instrument "dated this ........... day of ........................ I906" was denied probate because the day and month were omitted.55 An mstrument dated "Winters Yo lo Co Io I9I2" was denied probate on the ground that it lacked definiteness. ${ }^{58}$ The figures "ro" were followed by a space, after which the figures "Ig12" were written in a group, obviously intended to represent the year. While the court has held that a date may be abbreviated, (as will presently be shown), it was nevertheless held impossible to determine whether the number " 10 " represented, or was intended to represent, the 10th month of the calendar year or the 10th day of some other month.

An instrument dated "New York Nov. 22, 97" was wholly written and signed by the hand of the deceased. ${ }^{57}$ The court held that it was properly dated, that it was entirely unambiguous and to every one familiar with the usage of language, it expressed the month, day and year as clearly as though they had been written out in full. Upon the same principle, a date written "4-r4-07" was held propers8 and the court said that by growing usage and custom the method of designating the month, day and year by numerical abbreviation is so common that it would be difficult to find one at all versed in business or practical affairs, who would not readily and properly construe such numerical abbreviations.

If a date is partly written and partly primted the statute is not satisfied. ${ }^{59}$ So, a document dated "Sacramento April Ist I886" wherein the words "April rst" were written and the balance printed, was held invalid.60 A document dated "January I2, Ig04" wherein only the figures "I90" were printed, was held invalid.

53 Cal. Civ. Code, $\$ 1277$.

54 Estate of Anthony (1913), 21 Cal. App. 157, 131 Pac. 96.

55 Estate of Price, supra, n. 52.

58 Estate of Carpenter, supra, n. 52.

57 Estate of Lakemeyer (1901), 135 Cal. 28, 66 Pac. 961.

58 Estate of Chevallier (1911), 159 Cal. 161, 113 Pac. 130.

59 Estate of Billings (1884), 64 Cal. 427, 1 Pac. 701; Estate of Plumel (1907), 151 Cal. 77, 90 Pac. 192; Estate of Zollikofer (1914), 167 Cal. 196, 138 Pac. 995.

60 Estate of Billings, supra, n. 59.

61 Estate of Plumel, supra, n. 59. 
While a date may be abbreviated, it must still be definite and complete, ${ }^{62}$ even though it need not be a correct date, ${ }^{63}$ or a possible date. ${ }^{64}$ The writing of a will begun on one day may be concluded on a subsequent day, ${ }^{65}$ and the date first placed upon such a document may be adopted by the testator as the date of the instrument, even though there be a considerable lapse of time between the two occasions. ${ }^{68}$

In the Estate of Fay, ${ }^{\mathrm{B}}$ the instrument offered for probate was entirely written, dated and signed by the hand of the deceaset. The date the instrument bore was "May 25 1859". In this instrument the deceased made provision for a son who was born in I86r. It was obvious that the will was not written in 1859 and the court found, by conjecture, that the will was in fact written on May 25, 1889, the numerals " 59 " being inserted instead of the numerals " 89 " by mistake or carelessness. The court held that the instrument was a will, notwithstanding that an evident mistake had been made in the year of the date. The court points out that the legislature, in Section I277 of the Civil Code, did not use the words "truly dated" or "correctly dated," but merely the word "dated." The court indicated that, while the date is made necessary by statute, it is not a material element in the execution of an olographic will, but is merely a means of identification and aids in determining the authenticity of the will; and that the main and essential thing is that the will be wholly written and signed by the testator. To hold otherwise, the court indicated, would be to say that any difference shown between the date given in the instrument and the time when it was written would invalidate it.

This decision has been subjected to some criticism $^{68}$ upon the ground that the reasoning upon which it is based goes far toward establishing that the requirement of dating is directory rather than mandatory and that this is rather unsatisfactory, so long as it is conceded that the requirement must be obeyed. We beheve that the court disregarded the effect of legislative enactment

62 Estate of Vance (1916), 53 Cal. Dec. 1; see Vol. V, California Law Review, 266.

63 Estate of Clisby (1904), 145 Cal. 407, 78 Pac. 964.

B4 Estate of Fay (1904), 145 Cal. 82, 78 Pac. 340.

65 Castro v. Castro (1856), $6 \mathrm{Cal}$. 158.

66 Estate of Clisby, supra, n. 63.

67 (1904), 145 Cal. 82, 78 Pac. 340.

68104 Am. St. Rep. 17. 
when it stated that "the date is not an essential thing although made necessary by statute". This was, indeed, a departure from the earlier attitude of the court, as expressed in the Estate of Martin, ${ }^{69}$ and recently approved in the Estate of Vance, ${ }^{70}$ wherein it was held that the court was not "at liberty to hold that the legislature intended any one of the three requirements to be of greater or less importance than the other."

We are inclined to agree with the court in the statement of the rule, that a showing that an olographic will was actually made at a time different from the date written therein should not invalidate it; but it seems to us that if a date is to be regarded as an essential requirement, a line can clearly be drawn between the period of time when, during the life of the testator, a valid will was possible of execution and the period of time when it was not possible of execution. Every person over the age of eighteen years, of sound mind, may by last will dispose of his estate. Beginning with the date when a person arrives at the age of eighteen years and up to the date of his death, there is a period during which a will may be executed if the testator is of sound mind and not acting under duress, menace, fraud or undue influence. If a will is executed during this period but is dated at a time prior or subsequent to actual execution, but at a time within this period, then we would regard the date as a proper one, satisfying the statute. If, however, a will is executed during the period in which a will is possible of execution, but is dated at a time prior thereto, i. e., either before the person was born or before he reaches the age of eighteen, or subsequent thereto, i. e., after the death of the testator, then we would regard the date as improper and not a compliance with the statute. We recognize that this distinction may lead to some difficulties and may, on occasions, result harshly. ${ }^{\mathbf{1 1}}$

If, however, we are to regard dating as an essential requirement to an olographic will, the date should at least be required to be a possible date. If we are to regard dating merely as a means of identification and not as essential, as directory in character rather than mandatory, then let the statute be so amended in order that the doubt upon this point may forever be removed.

69 Supra, n. 50.

70 Supra, n. 62.

$71 \mathrm{It}$ is possible that this construction could not be made arbitrarily without legislation. 
While it may seem wrong to invalidate a will because one of the figures in the date is a clerical error, does it not seem just as wrong to invalidate a will because one of the figures in the date is printed? These matters cannot be discussed along the lines of what seems right or wrong. Either the statute has been complied with or it has not been complied with. If it has, then the document is entitled to probate. If it has not, probate should be denied.

In the Estate of Vance, ${ }^{72}$ an olographic instrument was wholly written and signed by the deceased and dated as follows:

"I have subscribed my name and affixed my seal this 22nd day of March, in the year of pur Lord one thousand."

This sentence appeared at the very bottom of the last page of the instrument. It appeared that the instrument was actually executed on March 22, 1910. The court held that

"... taking into consideration the nature, even more than the extent, of the discrepancy between the year given and the year of actual execution, the only fair inference is that Vance failed to complete the date which he had begun to write."

It was decided that the instrument was not an olographic will because " $a$ date which is incomplete, because lacking a statement of either the day, the month or the year of execution does not satisfy the statutory definition of an olographic will."

We believe this decision to be sound. We anticipate, however, that difficulties may arise in distinguishing between an incomplete date and an abbreviated date on one hand, and an incomplete date and an incorrect date on the other hand. If the Vance will had been dated in figures, "I000", the date would evidently have been complete but incorrect, and the will would have been valid under the Fay case.

In the course of its opinion in the Vance Estate, the court gives the following date, "November 22, I9 ", as an example of an incomplete date and states that it would be regarded as insufficient. Would it require a strained construction to construe the figures "I9 " as a numerical abbreviation of the year "I919"? If not, would not such a will be valid under the decisions in the Estates of Chevallier, Lakemeyer and Fay, even though it were an incorrect date? On the other hand, suppose a testator, executing a will in the year 1917, should begin to write the date, in

72 Supra, n. 62. 
words, and stop at that point in the date after the word "seven" and thereby fail to complete the word "seventeen". Is such a date to be regarded as complete but incorrect and valid under the Fay case or is it to be regarded as incomplete and therefore invalid under the Vance case? In such cases as these, precedents will afford little aid and eacl case will have to be decided upon its own peculiar facts.

\section{VI.}

An olographic will must be entirely signed by the hand of the testator.

It has for a long time been regarded as the established law of this state that Section 1277 of the Civil Code does not require that an olographic will "shall be subscribed by the testator at the end thereof." This requirement is in the language of Section I276 of the Civil Code with reference to attested wills. Section I277 of the Civil Code provides merely that an olographic will must be "signed" by the hand of the testator, and, in view of the distinction which the court felt the legislature had in mind between "subscribing" and "signing," it has been regarded as the rule of law in this state that a signing of an olographic will is valid, if it be at the beginning, at the end, or in any part of the document; and, if it be in the beginning or in any part of the document, that all that portion of the document following the siguature is to be construed as expressing the will of the deceased and effect is to be given, if possible, to all of the language found therein. ${ }^{73}$

The only linitation which apparently was placed upon this rule, until recently, was, in the event that the signature appeared to be in the beginning or in the body of the instrument, that the paper inust show upon its face that it is complete as a testamentary document. These early expressions of the Supreme Court of this state have practically been overruled in the Estate of Manchester. ${ }^{74}$

A docuinent olographic in character written wholly by the hand of the deceased, beginning as follows: "I, Matilda Manchester, leave and bequeath" etc., was then followed by a statement of devises and bequests, and the instrument ended as follows: "Whereunto I hereby set my hand this fourteenth day of Jan-

73 Estate of Stratton (1896), 112 Cal. 513, 44 Pac. 1028; Estate of Camp (1901), 134 Cal. 233, 66 Pac. 227; Estate of Barker (1875), Myricks Probate Reports, p. 78; Estate of Johnson (1872), Myricks Probate Reports, p. 5; Estate of Donoho (1877), Myricks Probate Reports, p. 140.

74 S. F. No. 7691, decided Feb. 15, 1917, 53 Cal. Dec. 220, 163 Pac. 358. 
uary I9I4". The name of the decedent does not appear in or upon the paper anywhere except in the opening clause. This instrument was placed in an envelope, sealed and endorsed by the decedent in her own handwriting with the words "My will, Ida Matilda Manchester". The court, setting aside the broadness and effect of its previous enunciations, held that this document was not signed in compliance with the provisions of Section I277 of the Civil Code. To sign, the court held, meant

"the signature of the testator in his own handwriting written somewhere in or upon the document with the intention by so writing to authenticate the document. The name written at another place than the end of the document and not for the purpose of authenticating it and indicating its completion but merely to identify the person who is making the will cannot be deemed to be a name 'signed' to the document."

The court considered the words in the concluding clause "whereunto I hereby set my hand" etc., as indicating that they were intended by the deceased to precede a signature and that they indicated that the decedent intended to sign immediately below and failed to carry out that intention.

In distingnishing the Estate of $\mathrm{Camp}^{75}$ and the Estate of Stratton $^{76}$ from the Manchester Estate, the court stated that the true rule is that

"wherever placed (referring to the signature) the fact that it was intended as an executing signature must satisfactorily appear on the face of the document itself. If it is at the end of the document, the universal custom of mankind forces the conclusion that it was appended as an execution, if nothing to the contrary appears. If placed elsewhere, it is for the court to say, from an inspection of the whole document, its language as well as its form, and the relative position of its parts, whether or not there is a positive and satisfactory inference from the document itself, that the siguature was so placed with the intent that it should there serve as a token of execution. If such inference thus appears, the execution may be considered as proven by such signature."

The foregoing now represents the latest rule enunciated by the Supreme Court with reference to the validity of a signature to an olographic will, and, in our opinion, is a more reasonable rule than was apparently laid down in the earlier decisions. One of the reasons given for the subscription of attested wills "at the 
end thereof" is that it prevents the interpolation of provisions between the end of the document, as the testator left it, and his signature. This reason should be equally applicable to olographic wills. We regard it as contrary to ordinary usage for a person to sign his name to as solemn a document as a will, by merely inserting it in the exordium or by having it appear in the body thereof. Would we ordinarily regard a promissory note, or any other contract, as duly signed, if the name of the debtor or party to the contract appeared only in the opening recital or in the body of the instrument? We see no reason for a different rule existing with reference to olographic wills.

It will frequently be difficult to determine from the face of an instrument not signed at the end, whether it is a complete and executed document and the Supreme Court of this state will always have the last word upon this subject.

In the Estate of McMahon, ${ }^{77}$ the writing was unwitnessed and unattested. It was olographic in character. In its exordium it declared, "This is the last will and testament of Elizabeth $R$. McMahon." Following this, the writing contained certain specific bequests and devises, with a residuary clause and a clause appointing an executor. It concluded as follows: "I do hereby publish and declare the foregoing, entirely written, dated and signed by my own hand, to be my last will and testament, this second day of January, 1912." No signature followed this declaration and no signature of the testatrix appeared in any other place upon the instrument save in the exordium, as above noted.

The court, mindful of its recent expressions in the Manchester Estate, ${ }^{78}$ announced that it must be established upon the face of the offered instrument that it is a complete and executed document; that

"notwithstanding that the usual place of signing and so of evidencing this execution and completeness is at the end of the instrument, the signature of the testator found elsewhere than at the end may be, if circumstances warrant it, a signature of execution, but that the only evidence which will wartant this conclusion must be found in and on the instrument itself; or, in other words, that the proof of this cannot rest in parol."

The court stated that absolute precision of execution is not expected in the case of an olographic will, but that the langnage

77 S. F. No. 7779, decided Feb. 16, 1917, 53 Cal. Dec. 225, 163 Pac. 669.

78 Supra, n. 74. 
in this case was "definite and convincing to the effect, not alone that the testatrix believed her will to be duly executed" but that the testatrix had

"sufficiently in law on the face of the instrument adopted the signature written by herself in the exordium of her will as her signature in execution of it. If she has done this and with sufficient exactitude has stated the fact, she has in legal effect declared that she has adopted her signature, as written in the body of the will, as being the signing of it $\mathrm{m}$ execution of it within the meaning of the code provision, and this would be sufficient to entitle the imstrument to probate."

The court held that the language last employed by the deceased clearly indicates that the testatrix had concluded her writing and thus had completed the expression of her testamentary intent and "it is a most reasonable construction of that language to say that she adopted her signature in the exordium" as her signature in the execution of the will.

While the language in the concluding clause of the instrument in the Manchester Estate is indeed different from that in the concluding clause of the instrument in the McMahon Estate, at the same time we feel that it does not necessarily appear in the McMahon Estate that it was the intention of the deceased to adopt her signature in the exordium, as her signature and authentication of the document itself. The will in the McMahon Estate was evidently drawn by a person of intelligence, who was advised with reference to legal expressions and versed, to some extent, in business transactions. We feel, therefore, that the court has probably credited the deceased with an erroneous intention concerning the effectiveness of her name as a signature as it appears in the exordium of the instrument.

Since it is so contrary to the ordinary, usual and customary act, to sign a document at the beginning or in the body thereof, the rule should be that when the signature of the deceased is found elsewhere than at the end, it must be considered invalid unless it unmistakably, definitely and unambiguously appears from the face of the instrument to have been the intention of the deceased to adopt the unusual signature as his actual signature to and in authentication of the document. In our opinion, hardly any. words other than those having substantially the following meaning, "I hereby adopt the writing of my name appearing in the beginning (or body) of this instrument as my-signature hereto," will indicate such an intent on the part of a testator. These are 
matters, however, upon which there may be honest differences of opinion, the final conclusion resting with the Supreme Court.

In the Estate of Manchester, it appeared that the decedent had enclosed the unsigned instrument in an envelope which she sealed and upon which she endorsed in her own handwriting the words "My will, Ida Matilda Manchester". The court held that the defect of a signature not appearing in the instrument was not cured by the words "my will", followed by the name of the deceased endorsed upon the envelope. The court indicated that the manifest purpose of the endorsement upon the envelope was to state that the paper within the envelope was the will of the deceased. It merely showed that the decedent believed that the enclosed docunient was her will and indicated that she believed that it was legally executed and valid, but the court proceeds to state "her belief that it was a valid will, properly executed, does not make it'so." This is the first case in which our Supreme Court has squarely passed upon the question, as to whether or not an endorsement, appearing upon an envelope in the handwriting of the deceased in which there is enclosed an olographic instrument, can be considered a part of the will. The decisions from different jurisdictions vary upon this point.

While the point was first raised in the Estate of Keith, ${ }^{79}$ it was unnecessary for the court to pass upon the question there, for the reason that one of the instruments enclosed in the envelope in the Keith Estate and which was sought to be admitted to probate, was not a testamentary document. It was urged, however, in the Estate of Manchester, that the endorsement on the envelope could be treated as a part of the document enclosed, as if it were an additional paper attached thereto, and that under the force of the decision in the Estate of Merryfield, ${ }^{80}$ the two papers should be construed together, making a complete testamentary scheme. The circumstances, the court held, "are utterly inconsistent with the idea that the endorsement was made for any such purpose". This rule conforms strictly to a recent case decided by the Supreme Court of Arizona, ${ }^{81}$ but is contrary to a recent decision from the State of North Carolina. ${ }^{82}$

79 Supra, n. 37.

80 Supra, n. 45.

81 Estate of Tyrrell (Ariz., 1915), 153 Pac. 767.

82 Alexander v. Johnston (1916), 88 S. E. (N. C.) 785. 
We have thus fully discussed under what circumstances, in what form and to what extent, documents entirely written, dated and signed by the hand of a deceased may be considered the olographic will of such deceased.

\section{Nat Schmulowitz.}

San Francisco, California, March, 1917.

(TO BE CONCLUDED IN NEXT ISSUE) 